Vol. 01, No. 01 Maret 2021, hlm. 25-34

Available at https://jurnal.unsur.ac.id/ar-rihlah/index

\title{
ANALISIS OPTIMALISASI DAMPAK PEMBINAAN CITRA PRODUK IKM TERHADAP DAYA SAING UMKM KABUPATEN CIANJUR \\ Kasmiri $^{1}$, Hana Amalia Sufiandi ${ }^{2}$ \\ ${ }^{1,2}$ Fakultas Ekonomi dan Bisnis Islam, Universitas Suryakancana kasmiricampaka105@gmail.com, deliahana17@gmail.com

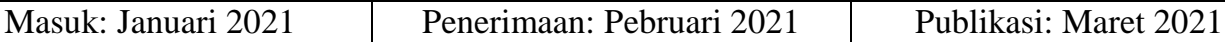

\begin{abstract}
ABSTRAK
Penelitian ini dilatar belakangi oleh adanya pembinaan terhadap Usaha Mikro Kecil dan Menengah (UMKM) sebagai produsen Industri Kecil Menengah (IKM) melalui program pembinaan fasilitasi yang telah diselenggarakan oleh DISKOPERDAGIN Kabupaten Cianjur terhadap UMKM dalam rangka meningkatkan citra produk IKM. Pembinaan yang telah diberikan berupa pembinaan fasilitasi untuk meningkatkan daya saing produk IKM melalui upaya peningkatan citra produk yang meliputi pembinaan fasilitasi P-IRT, label halal, desain kemasan, dan pendaftaran HAKI merek dagang. Tujuan penilitian ini adalah untuk menganalisis Optimalisasi dampak pembinaan citra produk IKM terhadap daya saing UMKM Kabupaten Cianjur (Studi Kasus Pembinaan UMKM pada DISKOPERDAGIN Kabupaten Cianjur). Pendekatan penelitian bersifat penelitian kualitatif dan kuantitatif, dengan metode penelitian analisis deskriptif. Data dikumpulkan melalui studi kepustakaan, observasi partisipatif dan wawancara selama melakukan Kuliah Kerja Lapangan. Temuan penelitian menyimpulkan bahwa pembinaan fasilitasi yang diberikan DISKOPERDAGIN dalam meningkatkan daya saing produk melalui pembinaan citra produk UMKM, seperti pembinaan fasilitasi PIRT,label halal, kemasan dan merek dagang ,nampak masih belum optimal untuk meningkatkan daya saing produk UMKM Kabupaten Cianjur, karena secara kuantitatif cakupan pembinaan fasilitasinya masih terbatas.
\end{abstract}

Kata Kunci: Pembinaan Fasilitasi UMKM, Citra Produk IKM, Daya saing UMKM

\section{ABSTRACT}

This research is motivated by implementation program of fasilitation for enchance competitive advantage of Cianjur IKM's product. The scope area program are fasilitation for PIRT sertificate, Halal's label, Packaging Design, and Brand Register product. The aims of this research to analyze optimalization impact of implementation DISKOPERDAGIN fasilitation program to enchance product competitive advantage of Cianjur IKM product. The methodology of this research are quantitative and qualitative research, with a descriptive analysis research method. Data was collected through literature study, par ticipatory observation and interviews was conducted during the KKL program in DIS KOPERDAGIN Cianjur District. Conclution of the research, that impact DISKOPERDAGIN fasilitation program to enchance IKM product's competitive advantage not yet. Qualitative that fhenomena condition occur from limited number participant program fasilitation coverage.

Keywords : UMKM fasilitation program, IKM Product Image and UMKM competitive advantage. 


\section{A. PENDAHULUAN}

Dalam era persaingan yang sangat ketat dewasa ini, dimana pasar nasional terintegrasi dengan pasar global telah menciptakan tantangan khusus kepada produk-produk hasil produksi UMKM untuk meningkatkan kemampuan daya saing mereka terhadap produk-produk sejenis hasil produksi manufaktur berskala menengah dan besar (Husaeni dan Dewi, 2019).

Dalam rangka meningkatkan citra produk UMKM, Dinas Koperasi Perdagangan dan Industri (DISKOPERDAGIN) Kabupaten Cianjur selaku dinas yang berperan dalam pembinaan UMKM telah menyelenggarakan program dan kegiatan untuk memberikan berbagai fasilitasi terhadap UMKM berupa fasilitasi pembinaan legalitas kesehatan usaha seperti untuk mendapatkan PIRT dari Dinas Kesehatan, sertifikasi label halal dari LPOM MUI, Hak Atas Kerkakayaan Intelektual (HAKI) merek dari MENKUMHAM.

Ketiga bentuk fasilitasi pembinaan (PIRT, Sertifkasi Halal dan HAKIMerek) tersebut merupaka hal yang strategis bagi peningkatan citra produk UMKM dalam meningkatkan citra produk UMKM menuju era persaingan di pasar local, nasional, bahkan global. Sertifikasi dan labelisasi halal bertujuan untuk memberikan kepastian hukum dan perlindungan terhadap konsumen, serta meningkatkan daya saing produk dalam negeri (Hamberi Bayu Dwi Saputra, 2016)

Secara geo - economic, Kabupaten Cianjur yang merupakan salah satu daerah tujuan wisata, menempati posisi strategis untuk berkembangnya industri produk-produk UMKM guna memenuhi pasar yang terus berkembang seiring dengan perkembangan industri kepariwisataan. Demikian pula, produk-produk industri kecil menengah (IKM) Cianjur, yang sebagaian besar merupakan produk industri rumah tangga (home industry) nampak akan terus berkembang dipengaruhi oleh permintaan pasar disekitar Cianjur yang juga merupakan daerah-daerah wisata, seperti Sukabumi, Bogor dan Bekasi (Florita et al., 2018).

Memperhatikan prospek pasar produk pangan hasil IKM dalam konstelasi perkembangan industri kepariwisataan wilayah Cianjur,Sukabumi, Bogor dan Bekasi, tersebut serta memperhatikan tuga pokok dan fungsi DISKOPERDAGIN Kabupaten Cianjur, peneliti tertarik untuk meneliti dampak fasilitasi pembinaan 
yang dilakukan DISKOPERDAGIN terhadap citra produk IKM di Kabupaten Cianjur.

Penelitian ini bertujuan untuk menganalisis seberapa besar dampak pembinaan fasilitasi DISKOPERDAGIN dalam memfasilitasi peningkatan citra produk IKM telah meningkatkan daya saing produk IKM di Kabupaten Cianjur.

Menurut kotler (2009) bahwa citra merek adalah persepsi masyarakat terhadap perusahaan atau produknya. Dengan demikian, dapat disimpulkan bahwa citra produk, citra perusahaan dan citra merek tidak dapat dipisahkan satu sama lainnya dan akan menjadi bagian penting dalam rangka meningkatkan daya saing produk. Oleh karena itu, dalam kasus produk IKM, ketiga hal itu harus terus menerus ditingkatkan fasilitasi pembinaannya. Temuan penelitian terdahulu menemukan bahwa label PIRT,label halal,desain kemasan dan merek produk berpengaruh terhadap keputusan pembelian para konsumen (Akim; Konety, Neneng; Purnama, Chandra; Adilla, 2018).

P-IRT yang merupakan salah satu prasarat produk UMKM untuk mampu bersaing dan memasuki pasar pada umumnya belum dimiliki oleh sebagian besar UMKM Kabupaten Cianjur. Demikian pula dengan label halal, desain kemasan serta merek yang terdaftar sebagai atribut citra produk yang merupakan faktor penting dalam meningkatkan daya saing produk, juga belum dimiliki oleh sebagian produk IKM Kabupaten Cianjur. Memperhatikan kondisi ini, peneliti tertarik untuk menganalisis Optimalisasi Dampak Pembinaan Citra Produk IKM Terhadap Daya Saing UMKM Kabupaten Cianjur (Hidayat \& Lisara, 2019).

\section{B. METODOLOGI PENELITIAN}

Pendekatan yang dilakukan dalam penelitian ini adalah pendekatan kualitatif dan kuantitatif. Pendekatan kualitatif dilakukan untuk menghasilkan uraian yang mendalam tentang ucapan, tulisan, dan perilaku yang dapat diamati dari suatu individu kelompok masyarakat, dan organisasi dalam suatu konteks tententu yang dikaji dari sudut pandang yang utuh, komprehensif, dan holistik. Penelitian kualitatif merupakan metode pengumpulan dan analisa datanya bersifat non kuantitatif dengan tujuan untuk mengeksplorasi hubungan sosial dan deskripsi realitas yang dialami responden (Saraclaers, 1993). 
Selanjutnya, dari data dan informasi yang diperoleh, peneliti akan menganalisis melalui pendekatan analisisis deskriptif untuk mendapatkan gambaran (deskripsi) kinerja DISKOPERDAGIN dalam program pembinaan fasilitasi untuk meningkatkan daya saing UMKM beserta alokasi dan sumber anggaran pembinaan UMKM. Teknik pengumpulan data meliputi : Studi kepustakaan, observasi partisipatif dan wawancara. Studi kepustakaan, dilakukan untuk mendapatkan data dan informasi tentang teori citra produk, citra merek dan kemasan serta data hasil pembinaan yang dilakukan oleh DISKOPERDAGIN. Data dan informasi diperoleh juga melalui hasil pengamatan peneliti selama melakukan KKL. Untuk melengkapi data yang diperoleh dari studi kepustakan dan observasi partisipatif, peneliti melakukan wawancara kepada narasumber yang melakukan pembinaan UMKM.

\section{HASIL DAN PEMBAHASAN}

\section{Hasil}

Berdasarkan hasil penelitian diperoleh data, di Kabupaten Cianjur terdapat sekitar 50.433 unit UMKM yang menghasilkan berbagai jenis produk IKM. Berdasarkan Undang-Undang Nomor 23 tahun 2014 tentang Pemerintahan Daerah bahwa Usaha Mikro Kecil Menengah (UMKM) merupakan salah satu urusan wajib yang harus diselenggarakan dalam rangka pelaksanaan otonomi daerah (Pratiwi Octasylva et al., 2020).

Disadari UMKM merupakan pelaku usaha di daerah yang mempunyai kedudukan dan peran strategis untuk meningkatkan perekonomian daerah sehingga diperlukan upaya perlindungan serta penciptaan peluang berusaha yang kondusif bagi UMKM agar mampu mewujudkan peran mereka secara optimal dalam pembangunan ekonomi daerah. DISKOPERDAGIN sebagai salah satu organisasi perangkat daerah (OPD) Kabupaten Cianjur merupakan OPD yang berperan dan berfungsi untuk merumuskan dan menyusun program serta berbagai kegiatan pembangunan dalam rangka meningkatkan kapasitas UMKM, baik dalam meningkatkan kapasitas kelembagaan maupun kapasitas usahanya. Dalam rangka meningkatkan daya saing UMKM sebagai produsen produk IKM, DISKOPERDAGIN Kabupaten Cianjur telah berupaya menyelenggarakan 
program pembinaan fasilitasi untuk meningkatkan kapasitas usaha dari UMKM yang terkait dengan peningkatan citra produk IKM.

Sampai saat ini telah terbina $10 \%$ dari total unit UMKM yang ada di Kabupaten Cainjur oleh DISKOPERDAGIN Kabupaten Cianjur. Pembinaan tersebut mencakup aspek legalitas, kemasan, merek dagang, dan teknik pemasaran.

Berikut ini disajikan data hasil dari pembinaan fasilitasi aspek legalitas, kemasan, merek dagang dan label halal yang diselenggarakan DISKOPERDAGIN Kabupaten Cianjur yang bersumber dari alokasi APBD Kabupaten Cianjur maupun dari Non APBD Kabupaten Cianjur.

Grafik 1: Jumlah UMKM Kabupaten Cianjur yang telah difasiltasi P-IRT

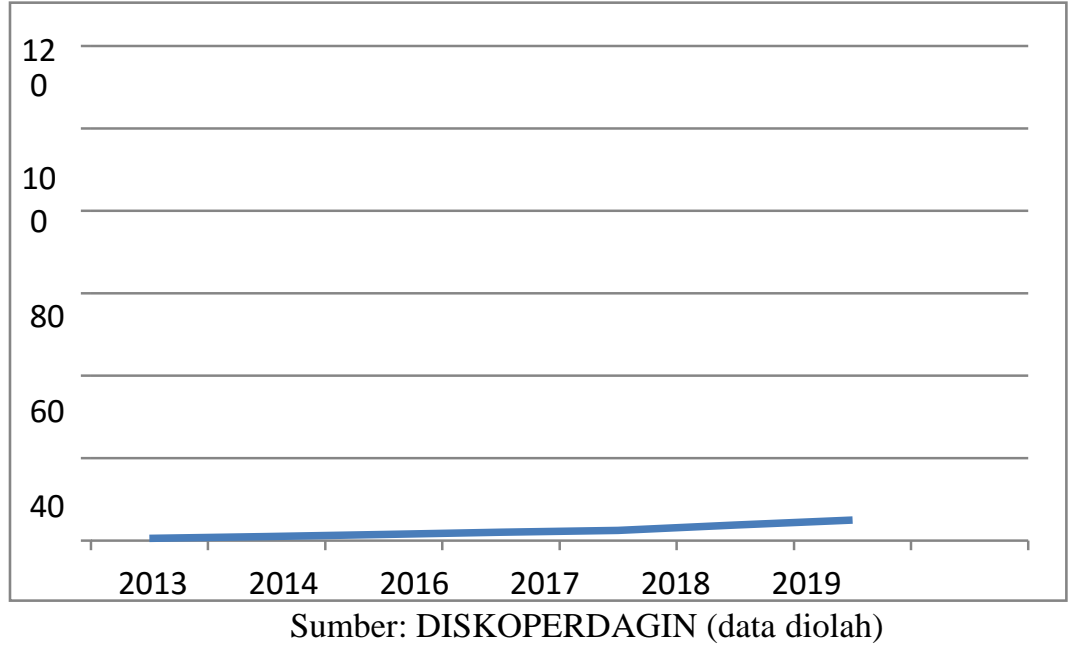

Dari grafik diatas, diperoleh gambaran bahwa pelaku UMKM yang memiliki P-IRT melalui program pembinaan fasilitasi DISKOPERDAGIN Kabupaten Cianjur hanya mencapai sebesar 5\% atau sekitar 2.500 unit UMKM dari total keseluruhan pelaku UMKM Kabupaten Cianjur yang berjumlah 50.433 unit. Aspek lainnya yang termasuk dalam atribut legalitas selain P-IRT adalah label halal. Dibawah ini merupakan data hasil fasilitasi pembinaan UMKM aspek label halal. 
Tabel 1

Rekapitulasi IKM Yang Sudah mendapat pembinaan

Fasilitasi Halal

\begin{tabular}{|l|l|c|c|c|c|}
\hline NO & TAHUN & $\begin{array}{c}\text { PRODUK } \\
\text { HALAL } \\
\text { DARI }\end{array}$ & $\begin{array}{c}\text { PRODUK HALAL } \\
\text { DARI ANGGARAN } \\
\text { APBD I }\end{array}$ & SWADAYA & JUMLAH \\
\hline 1 & 2014 & 0 & 159 & 0 & 159 \\
\hline 2 & 2015 & 0 & 100 & 0 & 100 \\
\hline 3 & 2016 & 0 & 9 & 0 & 9 \\
\hline 4 & 2017 & 23 & 24 & 0 & 47 \\
\hline 5 & 2018 & 50 & 8 & 0 & 60 \\
\hline 6 & 2019 & 50 & 10 & $\mathbf{0}$ & $\mathbf{4 3 3}$ \\
\hline \multicolumn{2}{|c|}{ TOTAL } & $\mathbf{1 2 3}$ & $\mathbf{3 1 0}$ & 0 & 58 \\
\hline
\end{tabular}

Sumber: DISKOPERDAGIN (data diolah)

Dari Tabel 1 diatas menunjukkan bahwa IKM yang sudah mendapat pembinaan fasilitasi label halal melalui program DISKOPERDAGIN Kabupaten Cianjur, berjumlah 433 unit IKM terdiri dari sebanyak 123 IKM dibina dan difasiltasi dari alokasi APBD II dan 310 IKM dari alokasi APBD I Provinsi Jawa Barat.

Pembinaan fasilitasi dalam rangka meningkatkan citra produk IKM lainnya adalah pembinaan fasilitasi kemasan produk dan pendaftar merek dagang dalam rangka mendapat Hak Atas Kekayaan Intelektual (HaKI) berupa merek terdaftar dari Dirjen HAKI Kementrian Hukum dan Ham Republik Indonesia. Hasil pembinaan fasilitasi di bidang kemasan, dan merek dagang mencakup pembinaan 200 Unit UMKM dan 10 Unit IKM, sedangkan untuk fasilitasi bina HAKI merek dagang adalah 15 unit IKM dari total unit UMKM Kabupaten Cainjur.

\section{Pembahasan}

Berdasarkan data hasil penelitian yang telah disajikan di atas, program pembinaan fasilitasi PIRT yang telah dilaksanakan nampak belum optimal dalam menjangkau jumlah UMKM Kabupaten Cianjur yang relative jumlahnya cukup banyak. Kondisi pembinaan fasilitasi PIRT ini menunjukkan, secara makro 
ekonomi nampak bahwa pembinaan fasilitasi PIRT belum berdampak optimal dalam rangka meningkatkan posisi daya saing produk IKM terhadap produk sejenis di pasar lokal dan nasional, alih-alih di pasar global (Primiana, 2013).

Sementara itu, kondisi pasar local dan nasional saat ini sudah terintegrasi dengan pasar global. Dalam arti, produk-produk sejenis produk IKM dari produsen luar negeri dengan kualitas jaminan keamanan dan kesehatan, serta desain kemasan menarik, bahkan berlabel halal telah merangsek masuk ke pasar lokal menyaingi produk IKM.

Berdasarkan data dan informasi seperti telah disajikan dan dikemukan, menunjukkan bahwa fasilitasi pembinaan UMKM yang dilakukan DISKOPERDAGIN terhadap citra produk UMKM belum optimal jika dibandingkan dengan besarnya jumlah UMKM yang ada di Kabupaten Cianjur sebesar 50.433 unit UMKM. Dengan demikian, secara makro fasilitasi yang diberikan tersebut nampak nya belum bisa mengangkat daya saing UMKM dari segi daya saing Citra produk dibandingkan dengan para pelaku usaha yang berskala besar. Para pelaku usaha besar, baik dari segi legalitas, label halal, kemasan dan merek dagang sudah memiliki citra produk yang lebih baik, dimana hal ini akan menjadi pesaing yang cukup berat bagi para pelaku UMKM (Ibrahim et al., 2019).

Memperhatikan data laporan akhir penelitian tentang peningkatan daya saing UMKM Jawa Barat dalam menopang perekonomian nasional menghadapi persaingan global ditinjau dari sisi supply chain,yang diselenggarakan oleh Fakultas Ekonomi dan Bisnis UNPAD, dikemukakan bahwa Jumlah UMKM di Jawa barat (2013) mencapai lebih dari 9.042.519 unit dan Usaha besar 1.853 unit. Perbandingan kontribusi UMKM dan Usaha besar terhadap PDRB Jawa Barat adalah 55:45.

Dengan demikian, keberadaan UMKM dalam pertumbuhan ekonomi Jawa Barat sangat signifikan, termasuk didalamnya peran dari UMKM Kabupaten Cianjur, sebagai salah satu Kabupaten dari Provinsi Jawa Barat. UMKM Kabupaten Cianjur yang berjumlah 50.433 unit atau sebesar...\% dari jumlah UMKM Provinsi Jawa Barat, sudah tentu berperan penting baik bagi pertumbuhan ekonomi Kabupaten Cianjur maupun bagi pertumbuhan ekonomi Provinsi Jawa 
Barat. Untuk itu, pengadaan alokasi sumber dana pembinaan untuk meningkatkan program fasilitasi dalam meningkatkan daya saing UMKM melalui peningkatan citra produk IKM harus menjadi salah satu prioritas, baik oleh Pemerintah Kabupaten Cianjur maupun oleh Provinsi Jawa Barat (Sadjoli et al., 2020).

Citra produk IKM tersebut harus menjadi prioritas dalam pembinaan IKM, mengingat atribut-atribut yang melekat pada citra produk IKM tersebut dapat mempengaruhi para konsumen produk IKM untuk melakukan pembelian. Atributatribut yang melekat pada produk IKM seperti PIRT, label halal, desain kemasan, merek dagang produk IKM, ternyata berdasarkan beberapa hasil penelitian telah berbengaruh terhadap keputusan membeli dari konsumen. Dengan semakin banyaknya jumlah UMKM penghasil produk IKM di Kabupaten Cianjur yang telah memiliki PIRT, label halal, kemasan produk yang menarik serta merek dagang yang terdaftar sebagai HAKI, diharapkan akan meningkatkan citra produk IKM Kabupaten Cianjur, baik di pasar local, nasional bahkan internasional. Sebaliknya, apabila kepemilikan PIRT, label halal, kemasan, dan merek dagang IKM secara relative masih kecil atau sedikit sekali dibanding produk industri besar (IB), nampaknya pilihan konsumen akan lelbih banyak terhadap produk IB yang memiliki keunggulan komparatif dalam jaminan kualitas produk (Suprapto \& Azizi, 2020).

Produk IB pada umumnya memiliki jaminan label MD/ML BPOM, label halal, desain kemasan menarik dan merek-merek terdaftar, serta label-label lainnya, seperti label standar nasional (SNI) dan label lingkungan (eco-label), apabila disandingkan dengan produk IKM sejenis dari UMKM, nampaknya akan berpengaruh terhadap konsumen dalam proses keputusan pembelian mereka.

Berdasarkan data cakupan program pembinaan fasilitasi DISKOPERDAGIN Kabupaten Cianjur dalam PIRT, sertifikasi label halal, desain kemasan dan pendaftaran HAKI merek dagang, dapat disimpulkan bahwa alokasi dana anggaran baik APBD Kabupaten Cianjur maupun APBD Provinsi Jawa Barat belum berdampak optimal terhadap peningkatan citra produk IKM Kabupaten Cianjur, baik di pasar local, nasional, atau global.Jadi,penyelengaraan program pembinaan fasilitasi produk IKM nampak belum berdampak optimal terhadap peningkatan posisi daya saing UMKM Kabupaten Cianjur. 


\section{KESIMPULAN}

Berdasarkan hasil penelitian dan pembahasan yang telah dikemukakan di atas, dapat disimpulkan, pertama dalam fasilitasi bina citra produk UMKM yang dilakukan DISKOPERDAGIN Kabupaten Cianjur belum dilakukan secara optimal, kedua Pengaruh fasilitasi program fsilitasi dalam peningkatan citra produk IKM melalui program fasilitasi PIRT, sertifikasi label halal, desain kemasan dan pendaftaran HAKI merek belum berdampak optimal terhadap peningkatan daya saing UMKM Kabupaten Cianjur, karena cakupan jumlahnya masih terbatas jika dibandingkan jumlah keberadaan UMKM yang relative cukup besar. Ketiga, pengetahuan UMKM terhadap strategi marketing mix (bauran pemasaran) dalam meningkatkan daya saing produk IKM dan posisi daya saing UMKM masih terbatas.

\section{REFERENSI}

Akim; Konety, Neneng; Purnama, Chandra; Adilla, M. H. (2018). The Understanding of Usaha Mikro, Kecil Dan Menengah (UMKM) in Jatinangor on the Obligation of Halal Certification on Food Products. Kumawula: Jurnal Pengabdian Kepada Masyarakat, 1(1), 31-49. http://jurnal.unpad.ac.id/kumawula/index

Florita, A., Jumiati, \& Mubarak, A. (2018). PEMBINAAN USAHA MIKRO, KECIL, DAN MENENGAH OLEH DINAS KOPERASI DAN UMKM KOTA PADANG. Pembinaan Usaha Mikro, Kecil, Dan Menengah Oleh Dinas Koperasi Dan Umkm Kota Padang, 1(1), 143-153.

Hidayat, S., \& Lisara, I. (2019). MENINGKATKAN DAYA SAING UMKM KICIMPRING MELALUI PROGRAM “MELEK UMKM. 8(1), 25-32.

Husaeni, Uus Ahmad, and Tini Kusmayati Dewi. "Pengaruh Pembiayaan Mikro Syariah Terhadap Tingkat Perkembangan Usaha Mikro Kecil Menengah (UMKM) pada Anggota BMT di Jawa Barat.” Bongaya Journal for Research in Management 2, no. 1 (2019): 48-56.

Ibrahim, M., Zainuddin, M., \& Surusa, F. E. P. (2019). Upaya Peningkatan Pemasaran Produk Melalui Pendampingan Pembuatan Nama Produk, Kemasan dan Perizinan Usaha Dodol Desa Reksonegoro Kabupaten Gorontalo. JATI EMAS (Jurnal Aplikasi Teknik Dan Pengabdian Masyarakat), 3(1), 29. https://doi.org/10.36339/je.v3i1.186

Pratiwi Octasylva, A. R., Leonita, S., \& Damang, S. M. (2020). Pelatihan Desain Kemasan Produk UMKM di Tangerang Selatan. Empowerment in the Community, 1(2), 41. https://doi.org/10.31543/ecj.v1i2.356

Primiana, I. (2013). Peningkatan Daya saing UMKM Jawa Barat Dalam Menopang Perekonomian Nasional. Journal of Chemical Information and Modeling, 
53(9), 1689-1699.

Sadjoli, N., Yuliati, R., Reynaldi, W., Anggraini, S. D., Debian, R., Yedidya, S., \& Kenneth, H. (2020). Peningkatan Daya Tarik Produk UMKM Teh Sereh Seungit dengan Kemasan Kekinian. Journal of Dedicators Community, 3(3), 58-72. https://doi.org/10.34001/jdc.v3i3.1022

Suprapto, R., \& Azizi, Z. W. (2020). Pengaruh Kemasan, Label Halal, Label Izin

P-Irt Terhadap Keputusan Pembelian Konsumen Umkm Kerupuk Ikan. Jurnal Riset Ekonomi Manajemen (REKOMEN), 3(2), 125-133. https://doi.org/10.31002/rn.v3i2.1984

Hana. Wawancara dengan Hery Suswandi, S.Sos, Tanggal 29 September 2020, di Kantor DISKOPERDAGIN Kabupaten Cianjur, pukul 10.00$12.00 \mathrm{WIB}$

Kementrian Koperasi dan Usaha Kecil dan Menengah, LAKIP Tahun 2018

Kotler, Philip dan Kevin Lane Keller. 2007. Manajemen Pemasaran edisi-12. Jakarta: PT Indeks

Raden Rudi Alhempi. Pengaruh Pelatihan dan Pembinaan terhadap Pengembangan Usaha Kecil pada Program Kemitraan Bina Lingkungan. Jurnal Bisnis dan Manajemen Vol. 13 No. 1

Sugiyono. 2005. Memahami Penelitian Kualitatif. Bandung: Alfabeta

Tambunan, Tulus TH. 2009. UMKM di Indonesia. Jakarta: PT. Ghalia Indonesia. 